\title{
Oil and gas companies in the innovation conditions of economic development in Kazakhstan
}

\author{
Sayabek Ziyadin ${ }^{1 *}$, Khakimzhan Malayev ${ }^{1}$, Gulmira Yessenova ${ }^{1}$, and Anar Beyzhanova ${ }^{2}$ \\ ${ }^{1}$ Al-Farabi Kazakh National University, 050040,71 Al-Farabi Ave, Almaty, Kazakhstan \\ ${ }^{2}$ L.N. Gumilyov Eurasian National University, 010000, 2 Satbayeva st. ,Nur-Sultan, Kazakhstan
}

\begin{abstract}
The article shows that the implementation of oil and gas companies will be implemented in many sectors of the global economy, including the main development sector-manufacturing industry. In Kazakhstan, "positive" experience has been accumulated in connection with the implementation of the oil and gas sector, because it is one of the main aspect of the global industries in our republic. The purpose of this article is to identify trends in the innovative development of the manufacturing industry, as well as to systematize the basic elements of the development industry and economic growth of the country. The correlation analysis will show how the innovation activity of the companies influencing on the GRP of the country. The potential of the company contains any and all available resources: financial, labor, material, immaterial and others, as well as the ability of managers to manage these resources in order to create products and services and to maximize earnings. For the purpose of getting the full company value the company's potential should be taken into account while applying the income method for valuation oil and gas companies, in calculating the discounted cash flows. The potential management can influence the value of a company and, consequently, the company management.
\end{abstract}

\section{Introduction}

Oil and gas sector is one of the global and comprehensive sectors in the Republic of Kazakhstan.

According for the President's announcement the energetic resources are specialized as one of the seven priorities of the country development till 2030 year. Oil and gas companies are the most specific factor which is playing the magnificent role in the economic development growth of the country.

If we consider oil and gas companies as one of the most popular factors in the management of cost estimates, the value of the company is a key indicator of its long-term performance, a kind of reflection of the improvement and development of the company. The development of the oil and gas sector contributes to the long-term development of

\footnotetext{
"Corresponding author: sayabekz@gmail.com
} 
economic levers of influence on capital investments, which ultimately contributes to the attraction of investors from outside, investments of the investor and growth of the investment attractiveness of the company.

The purpose of the article is to show and prove the possibility of further prospects for the development of oil and gas companies in this area, how the value assessment of the approaches and methods of the company is expressed, as well as what further actions of effective development of the potential of this type of companies and how they affect the economy as a whole. In order to achieve this goal, it is necessary to study and analyze the available methods of company management, approaches and methods of assessing the value of the company, as well as to define the concept of potential and its place in the management of the company.

The development of these types of companies should take into account whether the maximum benefit to the country is possible, given the development of the oil industry as a whole and the impact of the potential for an industrial sector of economic development.

Oil and gas companies specialized on the comparative analysis of cost estimates and opportunities to increase the value of equity capital through changes in the structure of assets, accumulation of funds in the main areas of the company's development and preservation of corporate control. The cost analysis methodology is integrated into the management decision making process. The fundamental principles of the company's valuation provide an understanding of the fundamental relationship between strategy, operations and financial results.

Recently, innovative technologies have been actively introduced in the mining industry, which can significantly reduce production costs, increase production efficiency and successfully develop mining projects that have recently been economically unprofitable. Supported by ongoing global economic growth and infrastructure development, the mining sector is becoming increasingly attractive to international investors looking for long-term and profitable investment opportunities. Currently, active work is underway in Kazakhstan and other countries of Central Asia to create favorable conditions for stimulating exploration and efficient reproduction of the mineral resource base; enhanced control over the rational and integrated use of the subsoil; new high-tech and effective technologies of geological exploration, production and processing of mineral raw materials are introduced using automated control processes; systematization of data banks of geological information; intensively developing industry infrastructure; conditions are being created for training personnel corresponding to modern industry requirements. The in-company mechanism of labor motivation is formed under the influence of a whole range of socio-economic factors, many of which represent rather independent subsystems of this mechanism. [1].

Given the current realities, it is necessary to solve a whole range of issues that allow the mining industry to be brought to a qualitatively higher level in terms of efficiency, productivity and safety.

This requires the fulfillment of at least three conditions:

1. Technical re-equipment of the industry, by introducing new, more efficient automated equipment;

2. Development of the latest processing technologies for extracted raw materials and natural resources;

3. Further training of personnel at mining enterprises at all levels.

World experience shows that the implementation of the above conditions is possible only with a close relationship between production and economic development. In other words, for more productive work of the manufacturing industry, it is necessary to implement projects within the industry of innovative activities based on the fruitful integration of Kazakhstan economy and the development of oil and gas companies. The purpose of this article is to identify trends in the innovative development of the oil and gas 
companies and to identify the correlation between two variables - GRP (economic growth) and development among of this kind of companies.

\section{Literature review}

Currently, innovation is an active link in all spheres of society. It is impossible to imagine the modern world without innovations that have already taken place and which have become habitual, and without future ones that contribute to further evolution. Most scholars agree that innovation has become the main driving force behind economic and social development.

Nick Antill and his colleague wrote in their research about the investment analysis how it will influence on the whole situation of market value is set by investor behaviour .

O'Dea, A., \& Flin, R. researched about the role and experiences of site managers in relation to safety have rarely been examined. A survey questionnaire was conducted of 200 Offshore Installation Managers (OIMs) from 157 offshore oil and gas installations belonging to 36 organisations.

Aboody, D. in his research work described and investigated the disclose the equvalent pricing consequences in oil and gas industry.

Sadorsky, P. in his work determined the risk factors in stock returns of Canadian oil and gas companies, how it will implement in the specific zones.

In an environment where research and development excellence, a high level of mastering new knowledge and creating innovative products are key factors that determine the competitiveness of national economies and the effectiveness of national security strategies, education priorities are changing, and this creates new models. Set of models represented part of the decision support system, which, through XML-environment and using SOAP-architecture allows managers to automate the process of selecting communication services. [2]. The basis for the construction of these models, according to several researchers, are the following innovative processes: in oil and gas sector of economy[3], automating the process of processing and researching data, but also in the intellectualization of information and organizational processes, the creation and implementation of effective methods and the intellectual and auxiliary decision-making technologies in oil companies [4], development optimization of investment portfolio of the oil and gas company [5], organization of a phase control system for the intensity of knowledge in accordance with established quantitative and qualitative criteria for achieving knowledge-based results (products, technologies, etc.) during the implementation of innovative projects [6]. Sayabek, Z., Ainur, M., Ulan, T., Gulvira, A., Aizhan, K., \& Zhanar, T. [7] consider the role of human capital, knowledge and high technology in innovative development. Tleppayev, A., Tovma, N., \& Zeinolla, S. researhed an important task in modern management is to increase energy efficiency as one of the key priorities of economic policy. The purpose of this paper is to develop a theoretical and methodological approach and practical recommendations aimed at the implementation of evaluation and monitoring of energy efficiency policy instruments. [8]

According to Mutanov, G., Ziyadin, S., Shaikh, A. [9], recently, the intensity of digital technology and innovation has been largely reflected in the level of sustainable economic development. In the context of global competition, this can be seen in those countries that provide favorable economic conditions and the benefits associated with innovation. The development of an innovative economy is an important prerequisite for increasing the country's competitiveness.

Ideally, to maintain competitiveness, mining aimed at long-term existence should be accompanied by a continuous search and implementation of innovative solutions. Although, often, innovations encounter certain difficulties of implementation, they are a 
source / reserve for a significant increase in the efficiency of mining operations and individual processes. This is especially necessary during periods of industrial crisis, when the optimization of production processes, cost reduction, increased sales efficiency due to the creation of new products, etc. take an important direction of development.

An analysis of recent studies and publications has shown that a number of works by domestic and foreign researchers are devoted to the study of innovation in the mining industry. Therefore, in the research of Lane, A., Guzek, J., \& Van Antwerpen, W. [10] characterized some of the big, difficult decisions faced by the mining industry in the South African context, and discusses how these decisions could be approached in a fact-based and robust way. Sganzerla, C., Seixas, C., \& Conti, A. [11] note the importance of the digital transformation of the mining industry. In their opinion, the possibilities for new operating models and new levels of optimization will create the next wave of differentiation in the industry. Seidaliyeva, D.A , Kirdasinova, K.A. [12] note in their research about the literature review of domestic and foreign authors, who studied the industrial development patterns and features of different countries, including the Republic of Kazakhstan. Milanez, B., \& de Oliveira, J. A. P. [13] argues that government funding and technical support dedicated to the development of mining clusters, i.e. working with small economic agents as a whole and not individually, could promote not only more economic development, but also effectively incorporate social and environmental issues, such as workers safety, water management and tailings recycling. In their studies, Shavina, E., \& Kalenov [14] consider the innovative technological development of the Russian mining regions (on the example of the Kemerovo region). According to Danabayeva, R., \& Shedenov, U. [15], sustainable innovation development of Kazakhstan: Challenges to transform science and technology should be the most attractive places for researching.

In the research paper of Martinez-Fernandez, C. [13] discusses the role of MTS firms in the transformation of the manufacturing industry into the knowledge economy. Results from a study of Australian MTS and mining firms suggest that innovation results from the interaction of these firms through knowledge-intensive service activities. In the research paper of Phelps, N. A., Atienza, M., \& Arias, M. take an initial step in this direction, identifying analytical dimensions to the enclave and illustrating different manifestations of enclaves in the mining industry, drawing on the case of Chile. Antill researched after a long period of cost cutting, the oil companies were left with little choice but to embark on a wave of mergers to rekindle growth aspirations. Aboody, D. wrote about focusing on research and development (R\&D) - an increasingly important yet poorly disclosed productive input - as a potential source of insider gains. Sadorsky, P. researched the results which are presented to show that exchange rates, crude oil prices and interest rates each have large and significant impacts on stock price returns in the oil and gas industry. Research paper of Giurco, D., \& Cooper, C. [16] applies the Mineral Resources Landscape to map stakeholder concerns for the case of deep-sea mining in Australia. It found that in exploring the future use of this technology to meet growing resource demand, the potential role of dematerialization and recycling were overlooked. The paper concludes with reflections on the usefulness of the approach for citizens, companies and governments.

Despite the presence of scientific interest in the study as a whole, currently the unresolved part is the problem of matters of systematization of technological solutions for the manufacturing industry of Kazakhstan. On this basis, there is a need for a more detailed study of the essence of oil and gas companies in the manufacturing industry and the identification of its main trends, since the lack of knowledge and lack of systematization of directions creates certain difficulties in the process of developing strategy. 


\section{Data and methodology}

\subsection{Data descriptions and analysis}

For the world's Top 40 miners, 2017 was a remarkable year. Thanks in large measure to the continuing recovery in commodity prices, fuelled by general economic growth, revenues rose dramatically by 23 per cent. At the same time, we can constructor the table 1 (Table 1).

Table 1. Data descriptions and analysis

\begin{tabular}{|c|c|c|c|c|}
\hline \multirow{2}{*}{ Metrics } & \multicolumn{4}{|c|}{ Years } \\
\cline { 2 - 5 } & 2015 & 2016 & 2017 & 2018 \\
\hline $\begin{array}{c}\text { GRP, milliard } \\
\text { tenge }\end{array}$ & 7599,9 & 8776,3 & 10542,5 & 12558,1 \\
\hline $\begin{array}{c}\text { Oil and gas } \\
\text { condensate } \\
\text { production }\end{array}$ & 52,2 & 61,2 & 70,4 & 75,2 \\
\hline $\begin{array}{c}\text { Attracting } \\
\text { foreign } \\
\text { investment in the } \\
\text { oil and gas sector }\end{array}$ & 1957,9 & 2870,8 & 3710,2 & 5410,2 \\
\hline $\begin{array}{c}\text { Oil exports, } \\
\text { including gas } \\
\text { condensate }\end{array}$ & 28,6 & 32,6 & 35,2 & 37,6 \\
\hline $\begin{array}{c}\text { Average price of } \\
\text { oil grade }\end{array}$ & 28,23 & 22,0 & 21,4 & 24,3 \\
\hline
\end{tabular}

\subsection{Methodology}

Use italics for variables $(u)$ and bold $(\mathbf{u})$ for vectors. The order for brackets should be $\{[()]\}$, except where brackets have special significance.

\section{Results and discussion}

Based on the use of production cyber physical systems in the forecast period due to the implementation of the management methodological base and the planned breakthrough technologies, in the course of the study, we prepared an enlarged systematization of technological elements for the mining industry (Figure 1).

*Compiled by the authors.

Systematization (see Figure 1) covers such areas of mining as:

1. Exploration of reserves and planning of mining operations;

2. Coal mining;

3. Processing of coal and industrial waste;

4. Transportation of coal and other goods.

In addition to the above methods and approaches to the management of modern tools for managing the development of the organization is the methodology of strategic management that meets the criteria and therefore takes place for further consideration of it.

The main goal of strategic management of the company is to maximize its value. Therefore, one of the most important theories of modern management is the cost approach to management. 
The basis of such management of the company is a comparative analysis of value assessment and opportunities to increase the value of equity capital through changes in the structure of assets, accumulation of funds in the main areas of the company's development and preservation of corporate control. Value analysis methodology is integrated into the process of developing management decisions. The fundamental principles of the company's valuation provide an understanding of the fundamental relationship between strategy, operations and financial results. Also Kazakhstan is the formation of a socially and environmentally oriented, profitable and competitive tourism industry that is able to supply the needs of tourists with various tourist services, bringing in revenues to the country and newly created jobs, including those defined with tourism in the sectors economy. [19]

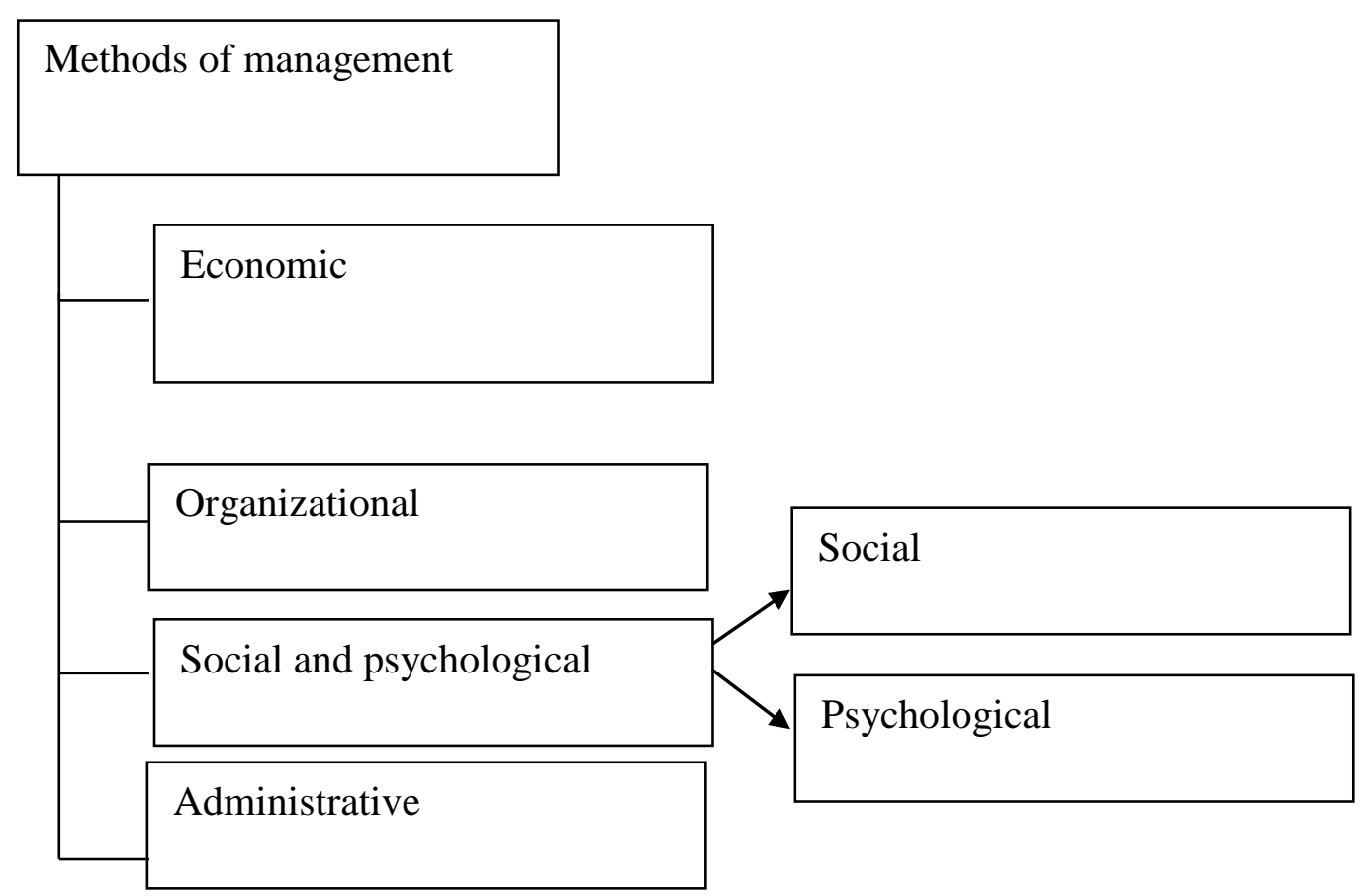

Fig. 1. Enhanced systematization of the basic elements on the basic processes of management methods.

\section{Conclusion}

In order to increase the efficiency of oil and gas resources use, Kazakhstan should continue to search and implement projects on transportation of Kazakhstani hydrocarbons to the most attractive markets, provided that transportation costs are minimized. Kazakhstani oil is transported both to the West through the CPC system, through Russian pipelines by tankers, and to the East through the Atasu-Alashankou pipeline. Kazakhstani oil will also be supplied to the Baku-Tbilisi-Ceyhan pipeline system.

Kazakhstan has long been a transit country for natural gas produced in Central Asia through Russia to Europe. In order to ensure energy security and gas supply to the South of the country, a project for the construction of the Beineu-Bozoi-Akbulak gas trunkline is being 
developed. The construction of the Caspian gas pipeline and the construction of the Kazakhstan-China gas pipeline continue.

Accelerated development of the oil and gas industry should be the driving force behind the socio-economic development of Kazakhstan. Oil projects should also provide jobs for local personnel and market the local industry, encouraging further growth. In the sphere of the fuel and energy complex, the world's largest states - the United States, Russia and China - have recognized Kazakhstan as a strategic partner. Deepening and developing relations with these countries is one of the most important areas of Kazakhstan's foreign policy.

Increasing the volume of oil and gas production and developing promising fields on the Caspian shelf requires dynamic development of oil and gas transportation infrastructure. In this regard, the work on creation of new and expansion of existing export systems is relevant. At present, a system has been practically created that gives oil producing companies operating in Kazakhstan the opportunity to choose the most attractive and stable markets for Kazakhstani oil.

Active development of oil and gas fields and a sharp increase in oil production in recent years dictate the need to utilize the ever-increasing volumes of produced associated gas. Efficient utilization of associated petroleum gas implies the maximum use of gas resources by generating electricity, producing marketable gas and injecting gas into the reservoir to enhance oil recovery.

At the same time, due to the growing role of the country in ensuring the energy security of the world economy and the need to ensure the efficient use of subsoil resources for the benefit of the people of Kazakhstan, the country is working to improve the legal mechanisms for regulating the subsoil use market.

\section{References}

1. N. Kurmanov, G. Kabdullina, M. Lim, B. Zhylkyshiev, Proceedings in ARSAAdvanced Research in Scientific Areas, 1 (2013)

2. R. Veynberg, A. Popov, Int. J. App. Engin. Res. 11(3), 1797-1802 (2016)

3. G. Mutanov, M. Milosz, A. Kozhanova, J. Engin. App. Sci. 13(10), 3396-3401 (2018)

4. M.A. Bahauovna, Int. J. App. Engin. Res , 10(23), 43446-434499 (2015)

5. R. Danabayeva, U. Shedenov, World App. Sci. J., 29(7), 852-855. (2014)

6. C. Sganzerla, C. Seixas, A. Conti, Proc. Engin. 138, 64-71. (2016)

7. S. Ziyadin, Y. Gulmira, Econ. Annals-XXI, 5-6, 37-40. (2015)

8. A. Tleppayev, N. Tovma, S. Zeinolla, In Vision 2020: Innovation Management, Development Sustainability, and Competitive Economic Growth, 3, 2071-2079 (2016)

9. G. Mutanov, S. Ziyadin, A. A. Shaikh, Enterpren. Sustain. Issues, 6(4) (2019)

10. A. Lane, J. Guzek, W. Van Antwerpen, J. South. Afr. Inst. Min. Metal.115(6), 471-479. (2015).

11. C. Sganzerla, C. Seixas, A. Conti, Proc. Engin 138, 64-71. (2016)

12. D. A. Seidaliyeva, K. A. Kirdasinova, S. K. Tazhikenova, A.T. Uskelenova, Z. B. Akhmetova, Int. J. Manag. Bus. Res. 8(1), 199-209 (2018)

13. C. Martinez-Fernandez, Serv. Indus. J. 30(1), 55-70. (2010)

14. E. Shavina, O. Kalenov, E3S Web of Conferences, 21, 04025 (2017)

15. R. Danabayeva, U. Shedenov, IBIMA (2013)

16. D.Giurco, C. Cooper, Miner. Engin. 29, 3-12 (2012)

17. S. Ziyadin, E. Streltsova, et al. Sustain. 11, 9, 2544 (2019)

18. N. A. Phelps, M. Atienza, M. Arias, Econ. Geogr. 91(2), 119-146. (2015)

19. S. Ziyadin, G. Dauliyeva, Zh. Kalymbekova, A. Turlybekova, IBIMA, 5, 20652070 (2017) 